\title{
PENGARUH BIAYA KUALITAS TERHADAP TINGKAT PENJUALAN PADA PT MITRA SEJATI MULIA INDUSTRI
}

\author{
Retno Martanti Endah Lestari \\ Dosen Tetap Fakultas Ekonomi \\ Universitas Pakuan \\ Muhammad Mahdi Hakim \\ Mahasiswa Fakultas Ekonomi \\ Universitas Pakuan
}

\begin{abstract}
ABSTRAK
PT Mitra Sejati Mulia Industri adalah perusahaan yang bergerak di bidang jasa CMT (cutting, making, trimming) dengan memproduksi polybag dari berbagai jenis dan ukuran sesuai dengan permintaan/pesanan pelanggan. Dalam penelitian ini peneliti memilih divisi polybag sebagai tempat penelitian disebabkan produk tersebut baru berkembang di perusahaan tersebut yang bergantung dengan tingkat pesanan pelanggan sehingga perusahaan harus mampu menciptakan produk yang sesuai dengan harapan pelanggan. Metode penelitian ini menggunakan analisis regresi berganda dan analisis statistik deskriptif dengan menggunakan control chart (peta kendali). Hasil penelitian diperoleh secara keseluruhan biaya kualitas mengalami peningkatan setiap tahunya, akan tetapi biaya-biaya tersebut secara keseluruhana dapat dikendalikan dengan baik oleh perusahaan. Peningkatan penjualan perusahaan dipengaruhi oleh biaya kualitas sedangkan sisanya dipengaruhi oleh faktor lain. Secara simultan biaya kualitas yang terdiri dari biaya pencegahan, biaya penilaian, biaya kegagalan internal, dan biaya kegagalan eksternal berpengaruh terhadap tingkat penjualan pada PT. Mitra Sejati Mulia Industri selama tahun 2009-2012. Secara parsial variabel biaya penilaian $\left(\mathrm{X}_{2}\right)$, biaya kegagalan internal $\left(\mathrm{X}_{3}\right)$, dan biaya kegagalan eksternal $\left(\mathrm{X}_{4}\right)$ berpengaruh secara signifikan terhadap tingkat penjualan, sedangkan variabel biaya pencegahan $\left(\mathrm{X}_{1}\right)$ tidak berpengaruh secara signifikan terhadap tingkat penjualan.
\end{abstract}

Kata Kunci: Biaya Pencegahan, Biaya Penilaian, Kegagalan Internal, Kegagalan Eksternal, dan Tingkat Penjualan.

\section{Pendahuluan}

Menjalankan bisnis dalam sebuah lingkungan global mengharuskan manajemen mengubah perspektifnya. Tujuan stategis perusahaan ialah meningkatkan laba perusahaan, memiliki nilai yang baik kepada komsumen dan juga memilki kemampuan daya saing dalam 
dunia bisnis. Perusahaan dapat mengembangkan keunggulan kompetitifnya yang didasarkan pada differensiasi produk dengan menciptakan inovasi-inovasi baru dan dengan didasarkan pada biaya rendah atau keduanya.

Suatu perusahaan dalam kondisi yang penuh persaingan harus dapat menciptakan dan mempertahankan keunggulan bersaing (competitive advantage). Salah satu strategi yang diterapkan oleh perusahaan dalam menghadapi persaingan untuk dapat memperoleh posisi di pasar (market place) sekaligus dapat mempertahankannya adalah dengan menciptakan suatu produk yang berkualitas. Kebutuhan akan produk yang berkualitas mendorong pelaku bisnis menciptakan suatu produk baik barang maupun jasa yang berkualitas.

Untuk menciptakan suatu produk yang berkualitas perusahaan harus selalu melakukan perencanaan, pengendalian, dan evaluasi terhadap produk yang dihasilkan dan juga distribusi produk yang baik sampai kepada pelanggan. Kualitas yang meningkat akan mengurangi terjadinya produk rusak sehingga akan meningkatkan kepusan pelanggan, meningkatkan harga jual, dan pada akhirnya meningkatkan penjualan. Kegiatan yang berhubungan dengan kualitasadalah kegiatan yang dilakukan kerena mungkin atau telah terdapat kualitas yang buruk yang akan menurunkan kualitas produk. Biaya-biaya yang berkaitan dengan kegiatan tersebut disebut Biaya Kualitas.

Biaya kualitas dibagi menjadi empat kategori, yaitu biaya pencegahan (prevention cost), biaya penilaian (appraisal cost), biaya kegagalan internal (intenal failure cost), biaya kegagalan eksternal (eksternal failure cost). Biaya-biaya tersebut mengimplikasi kepada dua subkategori dari kegiatan-kegiatan yang terkait dengan kualitas yaitu kegiatan pengendalian dan kegiatan karena kegagalan. Biaya pencegahan dan penilaian merupakan biaya yang digunakan dalam kegiatan pengendalian, yaitu aktivitas yang dilakukan perusahaan dalam mencegah atau mendeteksi kualitas yang buruk. Sedangkan biaya kegagalan internal dan kegagalan eksternal merupakan biaya yang digunakan dalam kegiatan karena kegagalan, yaitu aktivitas yang dilakukan perusahaan untuk merespon kualitas yang buruk.

Seharusnya dengan adanya pengendalian kualitas dan pengeluaran biaya-biaya terkait kualitas (biaya kualitas) perusahaan dapat merespons kualitas produk, baik setelah proses produksi maupun setelah produk tersebut telah didistribusikan kepada pelanggan. Agar produk yang dijual sesuai dengan harapan pelanggan, harga yang diharapkan perusahaan dan pengembalian barang (retur) dapat dihilangkan.

Begitu pula yang dihadapi oleh PT. Mitra Sejati Mulia Industri. Dalam proses perkembangannya, perusahaan dituntut memberikan hasil yang sesuai dengan 
harapan/keinginan pelanggan. Dengan demikian perusahaan harus bisa menciptakan produk yang berkualitas yang dapat memenuhi harapan pelangaan. Di dalam proses produksi, PT.Mitra Sejati Mulia harus mempunyai pengendalian kualitas (Quality Control) yang sangat ketat, mulai dari pesanan itu didapat, lalu pada saat merencanakan produksi, proses prosuksi, dan sampai dengan produk tersebut didistribusikan kepada pelanggan. Apabila PT. Mitra Sejati Mulia Industri tidak melakukan aktivitas pengendalian maka produk yang dihasilkan akan mengakibatkan banyaknya produk yang tidak berkualitas. Produk-produk yang tidak berkualitas ini apabila dijual akan terjadi ketidakpuasan pelanggan, banyaknya pengembalian barang (retur), hilangnya minat pelanggan, dan akan menurunkan harga jual. Seluruh fenomena tersebut secara langsung akan berdampak kepada penerimaan penjualan perusahaan.

Adapun tujuan dari penelitian ini adalah 1) Untuk mengetahui penerapan biaya kualitas yang terdiri dari biaya pencegahan, biaya penilaian, biaya kegagalan internal, dan biaya kegagalan eksternal yang terdapat pada PT. Mitra Sejati Mulia Industri; 2) Untuk mengetahui bagaimana kondisi tingkat penjualan perusahaan pada PT. Mitra Sejati Mulia Industri; 3) Untuk mengetahui pengaruh pengeluaran biaya kualitas yang terdiri dari biaya pencegahan, biaya penilaian, biaya kegagalan internal, dan biaya kegagalan eksternal terhadap tingkat penjualan pada PT. Mitra Sejati Mulia Industri.

\section{Metodologi Penelitian}

Analisis statistik inferensial yang digunakan dalam penelitian ini adalah analisis regresi berganda dan analisis statistic deskriptif dengan menggunakan control chart (peta kendali) dengan mempergunakan program SPSS for windows versi 20.

\section{Hasil dan Pembahasan}

\subsection{Biaya Kualitas Perusahaan}

Biaya kualitas dalam perusahaan manufaktur yang bergantung kepada pesanan pelanggan merupakan faktor yang sangat penting bagi menjaga kepercayaan dalam memenuhi kepuasan pelanggan. Biaya kualitas ini dapat mengurangi tinggat kerusakan produk, yang akan mengakibatkan menurunkan tingkat pengembalian barang (retur) barang, sehingga dapat meningkatkan tingkat penjualan.

Adapun biaya kualitas yang terdapat pada PT. Mitra Sejati Mulia Industri antara lain: 
1. Biaya Pencegahan, yaitu biaya yang terjadi untuk mencegah kualitas buruk pada produk atau jasa yang dihasilkan. Adapun biaya pencegahan yang terdapat pada PT. Mitra Sejati Mulia industri terdiri dari:
a. Biaya pelatihan karyawan;
b. Biaya perencanaan kualitas produk; dan
c. Biaya pengendalian proses kualitas.

2. Biaya Penilaian (Appraisal Cost), yaitu biaya yang terjadi untuk menentukan apakah produk atau jasa telah sesuai dengan persyaratan atau kebutuhan pelanggan. Adapun biaya penilaian yang terdapat pada PT. Mitra Sejati Mulia Industri adalah sebagai berikut:
a. Biaya inspeksi/pemeriksaan; dan
b. Biaya pengujian produk.

3. Biaya Kegagalan Internal (Internal Failure Cost), yaitu biaya yang terjadi karena produk dan jasa yang dihasilkan tidak sesuai dengan spesifikasi atau kebutuhan pelanggan. Adapun biaya kegagalan internal yang tedapat pada PT. Mitra Sejati Mulia Industri adalah sebagai berikut:
a. Material terbuang;
b. Biaya perbaikan atau pengerjaan ulang; dan
c. Biaya inspeksi dan pengujian ulang.

4. Biaya Kegagalan Eksternal (Internal Failure Cost), yaitu biaya yang terjadi karena produk atau jasa yang dihasilkan gagal memenuhi persyaratan atau tidak memuaskan kebutuhan pelanggan setalah produk telah disampaikan kepada pelanggan. Adapun biaya kegagalan eksternal yang terdapat pada PT. Mitra Sejati Mulia Industri adalah sebagai berikut:
a. Retur penjualan atau kegagalan dalam penjualan dan potongan penjualan; dan
b. Biaya garansi.

Biaya kualitas pada PT. Mitra Sejati Mulia Industri setiap tahunnya mengalami peningkatan, kacuali pada tahun 2012 biaya tersebut mengalami penurunan. Biaya kualitas yang meningkat tersebut juga diiringi dengan peningkatan penjualan setiap tahunnya. Biaya kualitas paling tinggi didominasi dari biaya penilaian seprti biaya inspeksi produk, dana biaya 
pengujian produk rata-rata setiap tahunya perusahaan mengeluarkan Rp. 28,513,625., dan biaya penilaian paling tinggi adalah pada tahun 2012 yaitu sebesar Rp. 35,753,100.,

\section{Gambar 1}

\section{Grafik Biaya Kualitas}

Tahun 2009-2012

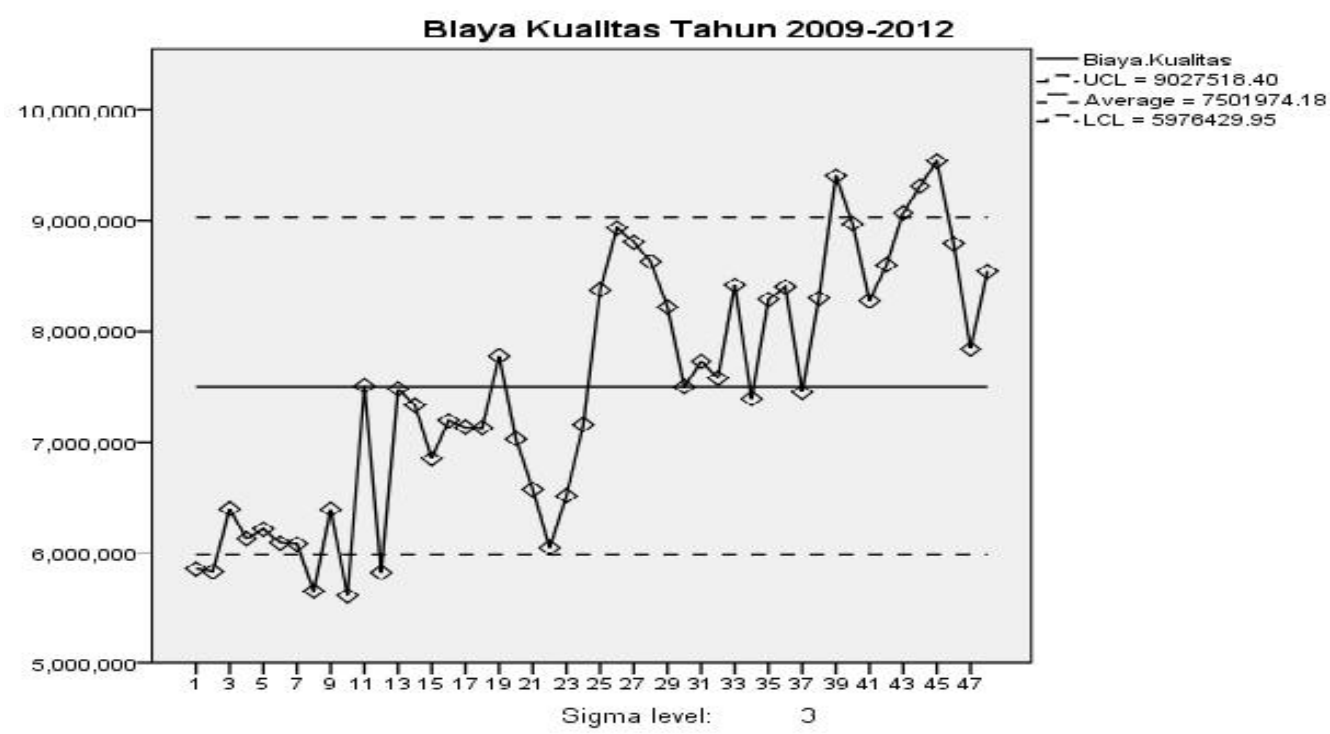

Secara keseluruhan biaya kualitas perusahaan dapat dikendalikan dengan baik, dari Gambar 1 terlihat bahwa biaya kualitas berada pada diantara garis LCL (lower control limit) dan UCL (upper control limit), akan tetapi pada beberapa bulan tahun 2012 terdapat biaya kualitas tersebut melewati garis UCL (upper control limit) akan tetapi tidak terlalu tinggi dan juga peningkatan biaya tersebut sebanding dengan meningkatnya tingkat penjualan perusahaan.

\subsection{Perkembangan Penjualan}

\section{Gambar 2}

\section{Grafik Tingkat Penjualan}




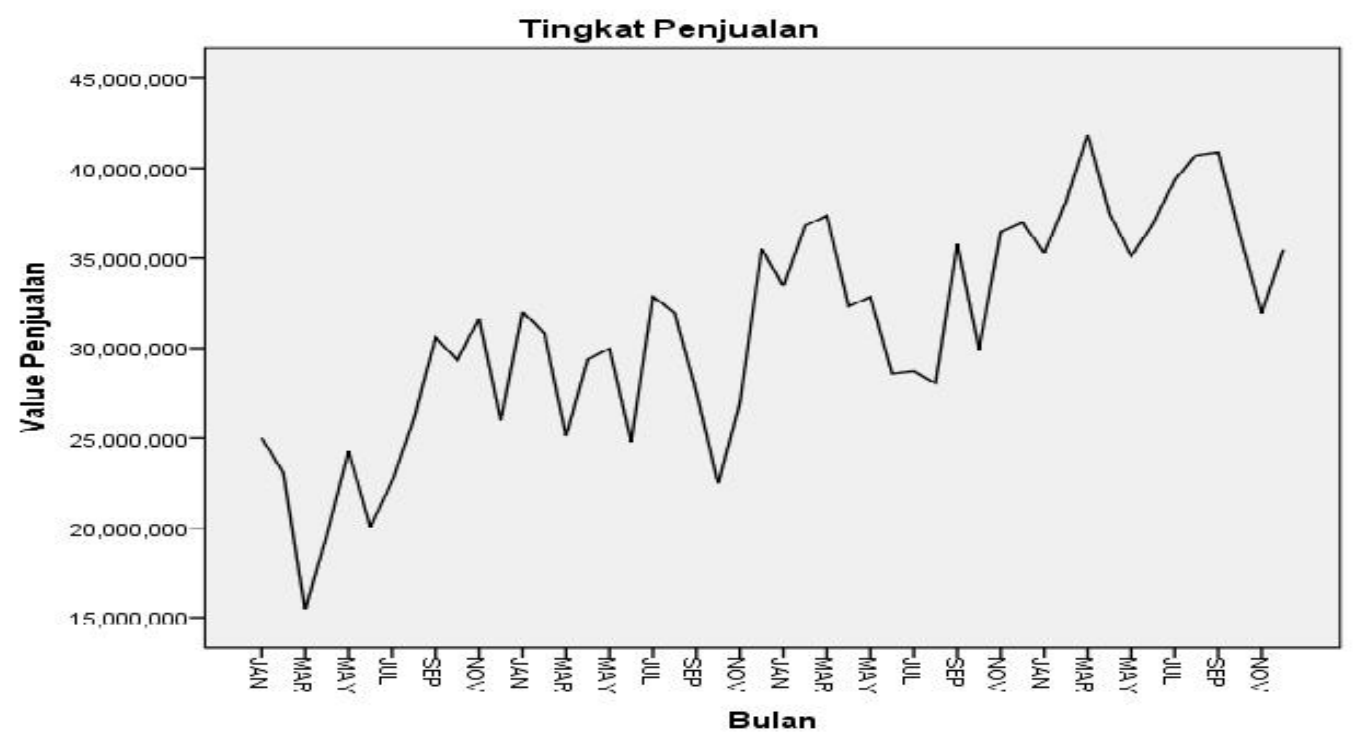

Pada Gambar 2 terlihat tingkat penjualan perusahaan mengalami fluktuasi, fluktuasi tersebut dikarnakan perusahaan tersebut penjualannya tergantung terhadap pesanan pelanggan, dan juga terdapat sejumlah kehilangan penjualan karena adanaya retur penualan. Akan tetapi dapat terlihat bahwa tren tingkat penjualan tersebut mengalami peningkatan dan dengan diiringi juga dengan tingkat retur panjualan dan tingkat potongan harga akibat adanya produk yang buruk yang semakin menurun, dengan kata lain perusahaan selalu melakukan peningkatan kualitas produknya sehinnga produk yang dihasilkan sesuai dengan spesifikasi pelanggan.

\subsection{Analisis Pengaruh Biaya Kualitas terhadap Tingkat Penjualan}

Dari hasil analisis regresi diperoleh persamaan $\mathrm{Y}=13908978.006+2,161\left(\mathrm{X}_{1}\right)+$ $4,161\left(X_{2}\right)+5,477\left(X_{3}\right)-5,943\left(X_{4}\right)$ hal ini berarti jika $X_{1}, X_{2}, X_{3}$, dan $X_{4}$ sama dengan nol (= 0) maka Y (penjualan) adalah sebesar 13908978.006; setiap ada penambahan biaya pencegahan $\left(\mathrm{X}_{1}\right)$ sebesar 1000 maka penjualan perusahaan perusahaan meningkat sebesar 2161; Pada saat biaya penilaian meningkat 1000 maka tingkat penjualan yang dihasilkan akan meningkat sebesar 4161;

Untuk pengujian hipotesis, dari Tabel 17 pengujian statistik secara parsial (Uji t) variabel biaya pencegahan diperoleh t hitung sebesar 1.793 dan nilai signifikansi sebesar 0,080. Karena nilai signifikansi lebih besar dari 0.05 (5\%) maka pada hipotesis 1 Ho diterima dan Ha ditolak, berarti tidak terdapat pengaruh signifikan antara variabel biaya pencegahan dengan variabel tingkat penjualan. Sedangkan untuk variabel biaya penilaian, biaya kegagalan internal, dan biaya kegagalan eksternal diperoleh thitung masing-masing 
sebesar 6.003,- 5.065,--7.074,- dan nilai signifikansi masing-masing sebesar 0,000. Karena nilai signifikansi lebih kecil dari 0.05 (5\%) oleh kerena itu maka untuk hipotesis 2, hipotesis 3, dan hipotesis 4 Ho ditolak dan Ha diterima, berarti terdapat pengaruh signifikan antara variabel biaya penilaian, variabel biaya kegagalan internal dan variabel kegagalan eksternal dengan variabel tingkat penjualan.

Berdasarkan hasil uji F (secara simultan) pengaruh biaya kualitas yang terdiri dari biaya pencegahan, biaya penilaian, biaya kegagalan internal, dan biaya kegagalan eksternal terhadap tingkat penjualan diatas, secara simultan biaya pencegahan, biaya penilaian, biaya kegagalan internal, dan biaya kegagalan eksternal berpengaruh secara signifikan terhadap tingkat penjualan oleh karena itu, maka. Hasil tabel 18 (ANOVA) dengan menggunakan tingkat signifikansi $\alpha=5 \%, F=208.565$ : signifikansi $=0,000$. Hasil ini memberikan dasar bagi penarikan kesimpulan bahwa pada hipotesis 5 Ho ditolak dan Ha diterima, artinya secara bersama-sama variabel independent (biaya pencegahan, biaya penilaian, biaya kegagalan internal, dan biaya kegagalan eksternal) berpengaruh terhadap variabel dependent (tingkat panjualan).

\section{Kesimpulan}

1. Secara keseluruhan biaya kualitas mengalami peningkatan setiap tahunya. Akan tetapi, biaya-biaya tersebut secara keseluruhana dapat dikendalikan dengan baik oleh perusahaan.

2. Peningkatan penjualan perusahaan yang dipengaruhi oleh biaya kualitas sedangkan sisanya dipengaruhi oleh variabel atau faktor lain yang tidak dikaji dalam penelitian ini.

3. Secara simultan atau bersama-sama variabel independen yaitu biaya kualitas yang terdiri dari biaya pencegahan, biaya penilaian, biaya kegagalan internal, dan biaya kegagalan eksternal berpengaruh terhadap tingkat penjualan pada PT. Mitra Sejati Mulia Industri selama tahun 2009-2012. Sedangkan secara parsial variabel biaya penilaian $\left(\mathrm{X}_{2}\right)$, biaya kegagalan internal $\left(\mathrm{X}_{3}\right)$, dan biaya kegagalan eksternal $\left(\mathrm{X}_{4}\right)$ berpengaruh secara signifikan terhadap tingkat penjualan, sedangkan variabel biaya pencegahan $\left(\mathrm{X}_{1}\right)$ tidak berpengaruh secara signifikan terhadap tingkat penjualan.

\section{Daftar Pustaka}


Andika, Wiekka Christiana. 2012. Pengaruh Biaya Kualitas Terhadap Pendapatan PLN Setelah ISO 900:2000 Periode 2004-2011 (Studi Pada PT. PLN (Persero) APJ Malang). Skripsi. Malang. Fakultas Ekonomi, Universitas Islam Negeri Maulana Malik Ibrahim.

Blocher, Edward J., Kung H. Chen, dan Thomas W. Lin. 2005. Manajemen Biaya dengan Tekanan Stratejik. Terjemahan A. Susty Ambarriani. Jakarta: Salemba Empat.

Hansen, Don R., \& Mowen, Marryane M. 2009. Akuntansi Manajerial. Edisi 8. Alih Bahasa: Dewi Fitriasari dan Deny Arnos Kwary. Jakarta: Salemba Empat.

Samryn, L. M. 2012. Akuntansi Manajemen: Informasi Biaya untuk Menegendalikan Aktivitas Operasi dan Informasi. Edisi Pertama. Jakarta: Kencana. 